\title{
RESEARCH
}

Open Access

\section{South Carolina forestland owners' willingness to accept compensations for carbon sequestration}

\author{
Mustapha Alhassan ${ }^{1,2^{*}}$, Marzieh Motallebi ${ }^{1}$ and Bo Song ${ }^{1}$
}

\begin{abstract}
Background: Carbon sequestration through recommended forest management practices is an ecosystem service that helps mitigate climate change and its impacts while generating carbon credits for forestland owners to sell in cap-and-trade programs. The California's cap-and-trade program (California's carbon market hereafter) allows forestland owners from any part of the contiguous United States to supply carbon credits to compliance entities. In this study, we estimate South Carolina (SC) private forestland owners' willingness to accept compensations to participate in the California's carbon market using a contingent valuation method.

Results: We estimate forestland owners' mean willingness to accept as $\$ 67$ per acre per year. Our results reveal higher probability of participation of forestland owners with interests in preserving forest ecosystems than those who do not. Additionally, forestland owners who trust in information about climate change from scientists or government are willing to participate more than those who do not.

Conclusions: Various factors hinder landowners' ability to participate in carbon markets. Forestland owners in SC consider legislative uncertainty and long-time commitment as the main barriers to participation in California's carbon market. From this research, average forestland tenure in SC is 27 years, which is far less than the 100-year time commitment of the California's carbon market. Of those who agreed to participate, choosing between adopting and not adopting any of the three main forest management practices in the California's carbon market: $28 \%$ are likely to adopt improved forest management (IFM) practices, $24 \%$ are likely to adopt reforestation due to understocked forestlands, and $14 \%$ are likely to adopt avoided conversion. In another development, the concept of aggregation has dominated discussions in the California's carbon market of late. It is an advocacy to include smallscale forestlands in the California's carbon market. To aggregate, different forestland owners will combine their forestlands to participate. We find that $79 \%$ of SC forestland owners are willing to aggregate to participate. However, this research is unable to determine how much total forestland is available in SC for carbon market. We recommend future research in the State on forestland owners' participation in carbon market should consider evaluating forestland availability.
\end{abstract}

Keywords: Forestland owners, Carbon markets, Willingness to accept

\footnotetext{
* Correspondence: malhassan@usgs.gov

${ }^{1}$ Clemson University, Baruch Institute of Coastal Ecology and Forest Science,

P. O. Box 596, Georgetown, SC 29442, USA

${ }^{2}$ Present Address: U.S. Geological Survey, Science and Decisions Center,

12201 Sunrise Valley Drive, Mail Stop 913, Reston, VA 20192, USA
} 


\section{Introduction}

Forests perform myriads of ecological functions including carbon sequestration, nutrient cycling, maintenance of wildlife habitat, and improvement of air and water quality. In particular, carbon sequestration through recommended forest management practices is an ecosystem service that helps mitigate climate change and its impacts (Jackson et al. 2008) while generating carbon credits for forestland owners to sell in carbon markets. In addressing environmental issues, market-based mechanisms including carbon emissions trading have become widely accepted as cost-effective approaches (Hamrick and Galant 2017), and forestland owners are expected to be among the largest suppliers of carbon credits in carbon emissions trading (Hein 2017). Forestlands account for approximately $67 \%$ of the total land area of South Carolina (SC), with $88 \%$ of the forestlands being owned and managed by private owners (SC Forestry Commission 2010; Brandeis et al. 2016). Approximately 67\% of private forestlands in SC are family owned with each family owning 65 acres (Poudyal et al. 2010). Of importance is the fact that only one-fifth of these private forestland owners ranked timber production as a chief management objective (Poudyal et al. 2010), suggesting proconservation behavior and potential for carbon market in the State. Furthermore, the South Carolina's forestry Best Management Practices (BMPs) offer guidelines to the State's forestland owners on good forest stewardship. The current BMPs include environmentally responsible timber harvesting operations, reforestation, and other operations to improve water quality and co-benefits (SC Forestry Commission 2018). These BMPs signal that it might be easier for forestland owners in the State to generate, maintain, and improve carbon stocks on their forestlands. However, forest owners have little or no information about how they can create and sell these carbon stocks as credits from their forestlands.

Carbon sequestration on private property is a climate resilient action and can provide vital information in advancing science-based policies to promote low carbon economy. In addressing climate change, private lands such as wetlands and agricultural lands or rangelands are identified as important carbon sinks (e.g. Cook and Ma 2014; Flint et al. 2018; Silver et al. 2018; Villa and Bernal 2018). In addition to carbon sequestration from private forestlands, the State of California has included carbon sequestration from rangelands in its climate change regulation (Flint et al. 2018; Silver et al. 2018).

Understanding private forestland owners' perceptions and willingness to participate in carbon markets is topical and of great importance in addressing climate change issues globally (Watson et al. 2018). Well managed forests can mitigate anthropogenic climate change (Bonan 2008), making forestland owners' decisions and forest management practices that sequester carbon worthy of investigation. This study has specific objectives including understanding perceptions of SC forestland owners with respect to opportunities, benefits, and barriers to participating in a carbon market. Another core objective is to identify which of the available forest management practices SC private forestland owners are likely to adopt for creating carbon credits. We evaluate the impact of the U.S. withdrawal from the Paris Agreement on SC forestland owners' decisions to participate in a carbon market. And most importantly, because carbon markets require long time commitments (CARB 2015b), we also investigate forestland tenure in SC.

We achieve these specific objectives using a survey-based method known as contingent valuation $(\mathrm{CV})$ to value carbon sequestration on private forestlands. Contingent valuation is a method of determining economic values of individuals for resources that do not have monetary value because they do not exist in a market (see Mitchell and Carson 2013). The CV method has its flaws including hypothetical biases (Loomis 2014), but these flaws can be addressed substantially through careful design of the questionnaire (Arrow et al. 1993) and appropriate statistical analysis of the survey results (Haab and McConnell 2003). Previous studies have used the $\mathrm{CV}$ method to determine forestland owners' willingness to participate in carbon markets (e.g., Markowski-Lindsay et al. 2011; Miller et al. 2012). Although these studies provide some insight in the range of benefits forestland owners are willing to accept (minimum compensations) for participating in carbon markets, they are all context and location-specific. They address perceptions of participating in carbon markets for category of forestland owners' (e.g. family forestland owners) in specific geographical locations, making their findings suitable for informing policies limited to only the study areas and type of forestland owners. However, due to differences in certain factors including forestland owner characteristics, motives for owning forests, forest type, and other regional differences, it is not yet known if SC forestland owners are willing to participate in carbon markets. Since majority of the State's land-cover is forestry and most forestland owners indicated they do not manage forests for timber, we conjecture some level of interest in participating in carbon market.

In the United States, an increasing number of studies have evaluated the potential of carbon markets for forestland owners in different parts of the country (Markowski-Lindsay et al. 2011; Khanal et al. 2017; Miller et al. 2012; Kelly et al. 2017). Kelly et al. (2017) investigate willingness of non-industrial private forestland owners in northern California to enter California's carbon market. They conclude that landowners' willingness to participate in California's carbon market is hindered by lack 
of information on the nature of the carbon market in addition to project development cost. Khanal et al. (2017) also examine willingness of non-industrial private forestland owners in selected states ${ }^{1}$ in the southern United States to manage their forestlands for carbon sequestration by delaying harvesting of timber for a maximum of 5 years, beyond scheduled harvesting periods. They find that while many landowners are willing to delay harvesting of timber for carbon sequestration provided it is profitable, others required little or no incentive payments to participate in forest carbon sequestration.

Another study by Miller et al. (2012) assesses interests of forestland owners in Michigan, Wisconsin and Minnesota in selling carbon credits for a maximum contract length of 50 years. They find that whereas longer contract length reduces willingness to participate, the probability of acceptance is still high among absentee landowners, and about $42 \%$ of landowners did not know about carbon credits. Miller et al. (2012) recommend that similar studies should be carried out in other regions of the United States to provide a more complete understanding of forestland owners' willingness to participate in carbon markets. Markowski-Lindsay et al. (2011) also investigate factors that motivate family forestland owners in Massachusetts to participate in carbon markets. They discover that even though most forestland owners do not have plans to cut trees for timber in the future, participation is low under current voluntary schemes and influenced by factors including early withdrawal penalties, contract length, and landowners' beliefs about climate change rather than price of carbon credits.

Each study relies on certain key factors in evaluating forest owners' preferences. Some of the studies used different contract lengths (e.g., Miller et al. 2012) to determine participation levels of forestland owners in carbon markets. In this study we use a fixed contract length of 100 years to reflect the forest offset protocol of the California Air Resources Board. The California's carbon market is currently the only compliance carbon market that accepts carbon credits from all parts of the United States and therefore suitable for our study. Others used family forest owners (e.g., Khanal et al. 2017; Kelly et al. 2017) but did not specify the minimum acres of forestland that qualified landowners to participate in their studies. Due to high costs of forest offset project development and relatively low current carbon offset prices (Hamrick and Galant 2017), participation in carbon market may not be financially viable for forestland owners including family forestland owners holding less than 100 acres of forestlands (Charnley et al. 2010). Personal communication with an Authorized Project Designee (APD) of a leading forest carbon offset developer firm, Green Assets, revealed that a minimum of 1000 acres is more cost effective to participate in California's carbon market. Also, Dickinson et al. (2012) find that the likelihood of Massachusetts' forestland owners' participation in carbon markets is higher among forestland owners with a minimum of 100 acres.

We therefore selected private forestland owners having a minimum of 100 acres of forestland. We elicited information about how much they are willing to accept as compensations to participate in California's carbon market, and the number of acres they are willing to allocate to participate. Because majority of forestland ownership in the U.S. is small-scale (Butler et al. 2016), it is advocated that CARB should allow different forest owners who do not have enough forestlands to combine their forestlands to participate in the California's carbon market. This process of combing forestlands is popularly known as aggregation. In this study, we also tried to investigate whether $\mathrm{SC}$ forestland owners are interested in aggregation.

\section{California's cap-and-trade program and forest offset protocol}

Assembly Bill 32 (AB 32), also known as the Global Warming Solutions Act of 2006, was enacted in California to reduce greenhouse gas (GHG) emissions in the state to 1990 levels by 2020 (Hsia-Kiung et al. 2014). It authorized the California Air Resources Board (CARB) to implement California's Cap-and-Trade Program (CA-CTP), which CARB enforced beginning in January 2013 (Hsia-Kiung et al. 2014). Assembly Bill 398 extends the CA-CTP program until 2030. The CA-CTP is part of the Western Climate Initiative, and it is the second largest carbon market in the world. The CA-CTP is a market-based directive to mitigate GHG emissions from multiple sources (CARB 2015a). Under the CA-CTP, the level of GHG emissions from regulated entities is set at a particular limit (cap) annually. Regulated entities acquire emission allowances through auctions to meet their compliance obligations. An entity with extra allowances can sell those it does not need to others (trade). Regulated entities in California acquire allowances through auctions and are allowed to obtain offsets, also known as carbon credits from sectors that are not covered by the cap including the forest sector in the United States. An offset is equivalent to one ton of carbon dioxide $\left(\mathrm{CO}_{2}\right)$ (Green Assets 2017), and it is the reduction in emissions of $\mathrm{CO}_{2}$ or GHGs (from sectors not covered by a cap) to compensate for emissions from regulated entities (Hsia-Kiung et al. 2014).

An important source of information about forest offset projects under CA-CTP is the forests offset protocol, designed by CARB to provide eligibility rules for forests in any part of the United States to generate and sell carbon credits in California's carbon market. Based on the 
forests offset protocol, forestland owners are required to register in California's carbon market and receive payments based on carbon sequestration potential of their forestlands. The forest must be managed using one of three management practices: improved forest management (IFM), reforestation, or avoided conversion (CARB 2015b). Management activities must be designed to increase or maintain carbon stocks on the forestland, and the forestland area can be contiguous or separated into tracts.

The IFM offset projects are currently the major projects in California's carbon market. Management activities recommended under the IFM offset projects include increasing rotation ages, thinning diseased and suppressed trees, increasing tree stocks, and maintaining stocks at a high level. Forestland for an IFM project can be private or public and must have more than $10 \%$ tree canopy cover. Reforestation offset projects are applied to forestlands that do not have optimal stocking levels of trees, and owners should have no intention to implement rotational harvesting for the next 30 years after commencement of reforestation projects, unless otherwise recommended. Reforestation projects must involve tree planting or removal of impediments to natural reforestation on lands with less than $10 \%$ tree cover for a minimum of 10 years. Reforestation is also required for land that has lost a minimum of $20 \%$ of aboveground standing live biomass due to disturbance. Avoided conversion offset projects require that forestlands are not converted to non-forest land uses and should have continuous forest cover with an eligible conservation easement. Forestlands under avoided conversion must be privately owned or transferred to public ownership prior to enrolling in California's carbon market.

There are many steps involved for forestland owners to participate in selling carbon credits in California's carbon market. Forestland owners are required to obtain an initial forest inventory of their forests by a professional forester to ensure that their forests will sequester carbon above a certain level. Carbon sequestration potential of the forests is then verified by a third-party verifier, and the project is registered with one of CARB-approved registries including the Climate Action Reserve, the American Carbon Registry, and the Verified Carbon Standard. Offsets are issued to the project account upon approval of the carbon project by CARB. The forestland owner is then instructed to keep a written record of the land management activities undertaken, in addition to verification and periodic monitoring by an independent third party.

\section{Theory and methods}

Forestland owners can choose to accept or reject the bid amounts offered to participate in a carbon market. They are assumed to be deterministic, rational utility maximizers, and choose the alternative with the highest utility. But since forestland owners' utilities are not known with certainty to the contingent valuation practitioner, they are treated as random variables under the random utility approach. To estimate minimum compensations forestland owners are willing to accept to participate in a carbon market, we therefore used a random utility model. The random utility model helps us to examine variations in the willingness to accept across characteristics of forestland owners and their forestlands. Our model also helps us to investigate forestland owners' motives for owning forestlands and how information itself and source of information about global climate change affect their willingness to participate in a carbon market.

In accordance with the theory of utility maximization, utility of supplying carbon credits to a carbon market for a forestland owner $j$ is modeled as a linear function of a set of forestland and forestland owners' characteristics $z_{j}=\left(z_{j 1}, \ldots, z_{j K}\right)$, the minimum price per acre $w_{j}$ the forestland owner is willing to accept (represented by the dollar value offered to the respondent), and the random error term $e_{i j}$, a set of unobservable characteristics. The maximum level of utility $V_{i j}$ of individual $j$ in state $i(i=$ 0 when forestland owner does not supply carbon credits, $i=1$ when forestland owner supplies carbon credits to carbon market) is represented in the form:

$$
V_{i j}=\alpha_{i 0}+\sum_{k=1}^{K} \alpha_{i k} z_{j k}+\beta w_{j}+e_{i j}
$$

where $\alpha_{i 0}, \alpha_{i k}(k=1, \ldots, K)$ and $\beta$ are coefficients to be estimated. Given that a forestland owner answered yes to $w_{j}$ to supply carbon credits, the forestland owner's utility when they supply the carbon credits, in rational choice perspective on behavior is more than or equal to that when they do not, can be shown as:

$$
V_{1 j} \geq V_{0 j}=\left(\alpha_{10}+\sum_{k=1}^{K} \alpha_{1 k} z_{j k}+\beta w_{j}+e_{1 j}\right) \geq\left(\alpha_{00}+\sum_{k=1}^{K} \alpha_{0 k} z_{j k}+e_{0 j}\right)
$$

This also implies that the probability that a forestland owner $j$ accepted $w_{j}$ is:

$$
\operatorname{Pr}\left(\text { yes }_{j}\right)=\operatorname{Pr}\left(\alpha_{10}+\sum_{k=1}^{K} \alpha_{1 k} z_{j k}+\beta w_{j}+e_{1 j}\right) \geq \operatorname{Pr}\left(\alpha_{00}+\sum_{k=1}^{K} \alpha_{0 k} z_{j k}+e_{0 j}\right)
$$

From Hanemann (1984) utility difference approach in measuring welfare, Eq. (2) can be expressed as:

$$
V_{j}^{*}=\alpha_{0}+\sum_{k=1}^{K} \alpha_{k} z_{j k}+\beta w_{j}+e_{j}
$$

where $V_{j}^{*}$ is a latent variable, unobservable utility index, 
represented by $0 / 1$ dichotomous dependent variable and indexes a forestland owner's utility to supply carbon credits. Assuming standard normal distribution of the willingness to accept random variable, the probability of agreeing to supply carbon credits given the amount offered is:

$$
\Phi\left[\left(\alpha_{0}+\sum_{k=1}^{K} \alpha_{k} z_{j k}+\beta w_{j}\right) / \sigma\right]
$$

where $\Phi$ represents the standard normal distribution and $\sigma$ represents the variance of the error term. A maximum likelihood approach is used in the estimation of parameters of Eq. (4), and the expected willingness to accept (WTA) of a forestland owner $j$ is calculated as

$$
E\left(W T A_{j}\right)=\left(\alpha_{0}+\sum_{k=1}^{K} \alpha_{k} z_{j k}\right) / \beta
$$

Average of the $E\left(W T A_{j}\right)$ represents the population average WTA.

\section{Questionnaire design and survey}

Our questionnaire was designed to elicit information that we hypothesized is likely to impact SC forestland owners' decisions to participate in the carbon market. We followed recommendations of the National Oceanic and Atmospheric Administration's (NOAA) blue ribbon panel in designing a contingent valuation survey (Arrow et al. 1993). The content of the questionnaire comprised an introduction and four sections: forestland and management, global climate change and risk perceptions, willingness to create and sell carbon credits, and other questions.

In the introduction, we explained to forestland owners the purpose of the survey and the benefits of creating and selling carbon credits. We also offered forestland owners the opportunity to opt out if they were not interested in participating in the survey. Under the forestland and management section, we asked questions on forestland characteristics and management activities. We also asked questions on forestland owners' values for owning forestlands.

Under the global climate change and perceptions section, we explained to respondents the anthropogenic causes of climate change as being from greenhouse gas (GHG) emissions by humans. We also mentioned to respondents the consequences of climate change including sea level rise, disturbance of marine ecosystems, severe water stress, natural disasters such as hurricanes, floods, droughts, heat waves, wild fires, and spreading of diseases. We then asked forestland owners questions about their knowledge of climate change and sources of information they trust when they hear about climate change.
The section on willingness to create and sell carbon credits explained to forestland owners the benefits of generating and selling carbon credits. It also mentioned the three forests management practices that are currently accepted in California's carbon market. We also revealed to the forestland owners that participation in the carbon market requires signing a contract to place their forestlands under easement for 100 years. After the explanation of the benefits of participating in carbon markets, we emphasized the impacts of climate change including research findings that predict the southern United States will be the hardest hit in terms of economic losses from climate change. For some respondents, we added information on the United States' withdrawal from the Paris Agreement:

... Efforts so far made by global leaders to combat climate change include the Paris Agreement. The Paris Agreement was negotiated in 2015 by many countries including the United States to hold global temperature rise below certain levels, through nationally determined contributions of reductions in emissions of carbon dioxide and other GHGs. It entered into force with over 80 countries, representing over $60 \%$ of global emissions, ratifying the agreement by the end of 2016.

\section{The Paris Agreement remains in force but the}

United States announced its withdrawal in 2017.

We intended to investigate how the United States' withdrawal from the Paris Agreement would impact forestland owners' decisions in combating climate change through participation in the carbon market. We proceeded with reminding respondents that it is generally known that some respondents are strategic in their responses in hypothetical surveys (Loomis 2014) like this, so they should answer with their willingness to accept truthfully. We followed this reminder immediately with the willingness to accept question in the form:

\section{Would you be willing to accept $\$$....... . per acre per year on your forestland for a period of 100 years of easement in order to create and sell carbon credits in California's carbon market?}

Forestland owners answered yes/no to the willingness to accept question. The final section of the questionnaire elicited sociodemographic characteristics of forestland owners.

Some survey questionnaires were sent out by mail while others were distributed online to South Carolina forestland owners by counties across the entire state using Qualtrics. Those who received surveys by mail were different from those who received surveys online through a link. We randomized among respondents 12 
versions of questionnaires from a combination of two types, with and without information on the Paris Agreement, and a set of six bid levels. The bid levels were determined through personal interviews with carbon offset developers and from the literature. These bid levels are shown in "Data" section. We first pretested the survey questionnaires among forestland owners during a carbon market workshop in South Carolina and revised the questionnaires for the main or final survey. The main survey was conducted from October 2017 to January 2018. We randomly selected forestland owners with minimum of 100 acres of forestlands. We obtained forestland owners' information from tax assessor's office of each county in SC. We first sent out 3000 surveys, followed by reminder of 1000 randomly selected forestland owners among those who failed to return their survey questionnaires. Reminder letters and survey questionnaires were sent to selected forestland owners. About 107 of the questionnaires were undeliverable due to change of addresses. At the end of the survey, we received 784 answered questionnaires, resulting in a response rate of about $27 \%$.

\section{Data}

In Table 1 is the number and percent of "yes" responses to the bid levels offered to the forestland owners to elicit their willingness to generate and sell carbon credits from their forestlands. The percent of yes responses represents the empirical probability distribution of the willingness to accept since a forestland owner who said yes to the offered bid is also likely to accept less than what is offered.

We present the empirical cumulative distribution function (CDF) of the yes responses in Fig. 1. In Fig. 1, the dash line, which is the trend line, shows that probability of acceptance of the bid to supply carbon credit increases with the bid levels, which is consistent with law of supply.

Table 2 shows the summary statistics and definition of selected variables. About 32\% of the forestland owners accepted the bids offered to create and sell carbon credits. Average forestland from our study is about 1820

Table 1 Number and percent of "yes" responses to the bids

\begin{tabular}{lllll}
\hline \$bid & No & Yes & Percent yes & Total \\
\hline 7 & 66 & 17 & 20.48 & 83 \\
11 & 65 & 36 & 35.64 & 101 \\
25 & 70 & 39 & 35.78 & 109 \\
40 & 45 & 33 & 42.31 & 78 \\
50 & 49 & 43 & 46.74 & 92 \\
65 & 66 & 38 & 36.54 & 104 \\
Total & 361 & 206 & & 567 \\
\hline
\end{tabular}

acres. About 23\% of the forestland owners reported they already have their forestlands under conservation easements or other land programs. About $49 \%$ of the forestland owners received versions of the questionnaire that had information on the United States' withdrawal from the Paris Agreement. The sociodemographic information of the forestland owners shows that $71 \%$ are males. Average years of education is about 17 and average 2016 income is $\$ 138,476$. Number of years of forestland ownership in SC ranges from 1 to 150 with an average of about 26.97 years.

A Likert scale question, presented in Fig. 2 to understand importance of owning a forestland reveals that $37 \%$ of forestland owners said ecosystem services (carbon sequestration, water quality improvement, wildlife habitat protection, nutrient cycling, and recreation) other than timber from forestlands are very important to them. About $41 \%$ said ecosystem services are important to them, $16 \%$ said ecosystems services are slightly important, and only $6 \%$ of forestland owners said ecosystem services are not important to them.

Figure 3 shows forestland owners' trust in source of information about climate change. Comparing climate change information from government (federal, state, or local), 38\% of forestland owners indicated a high trust in scientists, while $7 \%$ indicated a high trust in government. A moderate trust in information from scientists was $44 \%$, while that in government was $32 \%$. Thirteen percent of forestland owners have low trust in scientists and $36 \%$ had a low trust in government. Also, only $5 \%$ of forestland owners reported they have no trust in scientist while $25 \%$ expressed no trust in government as their source of climate change information. From our data, forestland owners indicated high trust in climate change information from scientists than from government. A study in Australian rural residents' perceptions of climate change and trust in sources of information about climate change also show high trust in information from scientists compared with politicians, government, and media as sources (Buys et al. 2014).

On a scale of $1-5$, where 1 represents "not a barrier" and 5 represents a "considerable barrier," we also asked forestland owners to rate factors comprising price uncertainty of carbon credits, initial development costs of forests offset projects, long time commitment such as 100 years of easement, legislative uncertainty, and competing environmental programs, such as forest conservation programs, as perceived barriers to participation in carbon markets. The perceived barriers are shown in Fig. 4 . Using averages of the ratings, forestland owners perceived legislative uncertainty to be the most considerable barrier given an average rating of 3.83, followed by long time commitment with an average rating of 3.82 . The rest of the ratings are 3.61 for initial development cost 


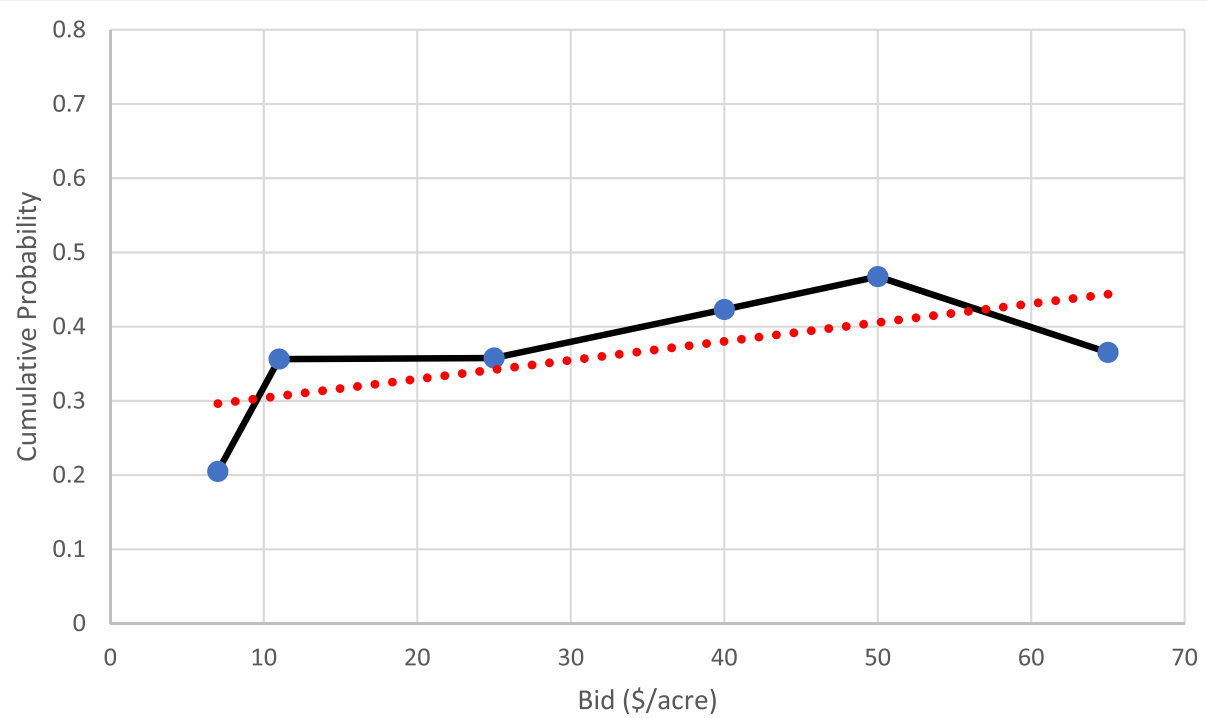

Fig. 1 Cumulative probability of yes responses to the bids

as the third most considerable barrier, and 3.57 for price uncertainty as the fourth considerable barrier. Forestland owners considered competing environmental programs as the least barrier to participating in the California's carbon market with a rating of 2.97 .

In Fig. 5, the question on which forest management practice (improved forest management (IFM), avoided conversion (AC), and reforestation), SC forestland owners are likely to adopt in order to participate in California's cap-and-trade program revealed that $28 \%$ of them are willing to adopt IFM, $14 \%$ are willing to adopt $\mathrm{AC}$, and $24 \%$ would adopt reforestation. The data also show that the average acres forestland owners agreed to use to participate is 1292.40 . In addition, about $79 \%$ of the forestland owners agreed they would be willing to aggregate their forestlands with others to generate and sell carbon credits. Aggregation may be an option to consider since it is not possible for forestland owners with fewer acres to participate in the California's carbon market.

\section{Results and discussion}

The main objective of this study is to estimate minimum monetary compensations at which forestland owners are willing to supply carbon credits to California's carbon market. We used a random utility Probit model to approximate the willingness to accept (WTA) distribution function from which the WTA is calculated. Table 3 presents the probability of accepting the offered bids given characteristics of the respondents (Probit estimates) and the marginal effects of the WTA. We selected our variables based on the hypotheses we wanted to test and fitted two models, restricted and unrestricted. In the second and third columns of Table 3 are the coefficients and marginal effects of our restricted model, respectively. The restricted model does not control for forestland owners' trust of information about climate change from scientist and government.

In the restricted model, the significant variables are bid, ecosystems2, ecosystems3, ecosystems4, and gender. The marginal effect of the bid variable is positive which indicates that forestland owners were accepting larger amounts posed to them more than the smaller amounts. It interprets that a dollar increase in the bid level would increase probability of willingness to accept by 0.003 . Our result is consistent with the finding of Miller et al. (2012) who estimated the marginal effect of Lake States' family forestland owners' willingness to supply carbon credits to California's carbon market as 0.008. Poudyal et al. (2010) also find probability of municipal government's participation in carbon market given importance of potential income from carbon credits to be 0.08 in the United States. Dickinson et al. (2012) also find a positive but low acceptance rate of net revenue per acre per year offered to non-industrial private forestland owners in Massachusetts to participate in carbon market. These findings are legitimate because, being suppliers of carbon credits, forestland owners are willing to supply when price of carbon credit is high. Given the significance of the marginal effect of the ecoystem 2 variable, probability of willingness to participate in a carbon market decreases by 0.14 for forestland owners who consider ecosystem services as one of the important reasons they own forestlands, compared with those who consider ecosystem services as very important. Probability of willingness to participate goes down by 0.22 for those who consider ecosystem services to be slightly important, as shown by the marginal effect of the ecosystem3, 
Table 2 Summary statistics and definition of selected variables

\begin{tabular}{|c|c|c|c|c|c|c|}
\hline Variable & Definition & Obs & Mean & Std. Dev. & Min & Max \\
\hline \multicolumn{7}{|l|}{ Valuation: } \\
\hline Yes/no & Response to the bid ( 1 if yes; 0 for no). & 647 & 0.32 & 0.47 & 0 & 1 \\
\hline Bid & Dollar amount offered to forestland owners. & 567 & 33.33 & 20.97 & 7 & 65 \\
\hline \multicolumn{7}{|c|}{ Forestland \& Ecosystem Services: } \\
\hline Forestland & Total forestland owned in acres. & 565 & 1820.96 & 6939.91 & 100 & 80,000 \\
\hline Credit acres & Reported acres of forestland to use in carbon market. & 201 & 1292.41 & 5762.22 & 20 & 70,000 \\
\hline Years owned & Number of years a forestland is owned. & 555 & 26.97 & 19.82 & 1 & 150 \\
\hline Easement & If forestland is in easement ( 1 if "yes"; 0 for "No"). & 647 & 0.23 & 0.42 & 0 & 1 \\
\hline Ecosystems 1 & How important are ecosystem services to you ( 1 if very important; 0 otherwise). & 559 & 0.37 & 0.48 & 0 & 1 \\
\hline Ecosystems2 & How important are ecosystem services to you (1 if important; 0 otherwise). & 559 & 0.41 & 0.49 & 0 & 1 \\
\hline Ecosystems3 & How important are ecosystem services to you (1 if slightly important; 0 otherwise). & 559 & 0.16 & 0.37 & 0 & 1 \\
\hline Ecosystems 4 & How important are ecosystem services to you ( 1 if not important; 0 otherwise). & 559 & 0.06 & 0.24 & 0 & 1 \\
\hline Aggregation & $\begin{array}{l}\text { Whether owner is willing to combine forestland with owners to participate ( } 1 \text { if yes; } 0 \text { if } \\
\text { no). }\end{array}$ & 192 & 0.79 & 0.41 & 0 & 1 \\
\hline \multicolumn{7}{|c|}{ Information \& Trust: } \\
\hline Paris & Information on Paris Accord. & 541 & 0.49 & 0.5 & 0 & 1 \\
\hline Scientist1 & $\begin{array}{l}\text { How much you trust information about climate change from a scientist (1 if high; } 0 \\
\text { otherwise). }\end{array}$ & 557 & 0.38 & 0.49 & 0 & 1 \\
\hline Scientist2 & $\begin{array}{l}\text { How much you trust information about climate change from a scientist ( } 1 \text { if moderate; } \\
0 \text { otherwise). }\end{array}$ & 557 & 0.44 & 0.5 & 0 & 1 \\
\hline Scientist3 & $\begin{array}{l}\text { How much you trust information about climate change from a scientist (1 if low; } 0 \\
\text { otherwise). }\end{array}$ & 557 & 0.13 & 0.34 & 0 & 1 \\
\hline Scientist4 & $\begin{array}{l}\text { How much you trust information about climate change from a scientist ( } 1 \text { if none; } 0 \\
\text { otherwise). }\end{array}$ & 557 & 0.05 & 0.22 & 0 & 1 \\
\hline Government1 & $\begin{array}{l}\text { How much you trust information about climate change from government ( } 1 \text { if high; } 0 \\
\text { otherwise). }\end{array}$ & 561 & 0.07 & 0.25 & 0 & 1 \\
\hline Government2 & $\begin{array}{l}\text { How much you trust information about climate change from government ( } 1 \text { if } \\
\text { moderate; } 0 \text { otherwise). }\end{array}$ & 561 & 0.32 & 0.47 & 0 & 1 \\
\hline Government3 & $\begin{array}{l}\text { How much you trust information about climate change from government ( } 1 \text { if low; } 0 \\
\text { otherwise). }\end{array}$ & 561 & 0.36 & 0.48 & 0 & 1 \\
\hline Government4 & $\begin{array}{l}\text { How much you trust information about climate change from government ( } 1 \text { if none; } 0 \\
\text { otherwise). }\end{array}$ & 561 & 0.25 & 0.43 & 0 & 1 \\
\hline \multicolumn{7}{|c|}{ Sociodemographic: } \\
\hline Gender & 1 if male; 0 otherwise. & 647 & 0.71 & 0.45 & 0 & 1 \\
\hline Education & Level of education in years. & 558 & 17.05 & 1.95 & 9 & 19 \\
\hline Income & Average 2016 household income in dollars. & 461 & $138,476.1$ & $64,958.15$ & 5000 & 212,500 \\
\hline
\end{tabular}

compared with those who see it to be a very important reason for owning forestland. For forestland owners who don't consider ecosystem services to be part of the important reasons they own forestlands, their probability of willingness to participate is lower by 0.38 , indicated by the marginal effect of ecoystem4, compared with those who consider ecosystem services to be very important.

Our findings suggest that probability of participation in California's carbon market is higher among forestland owners with large forest ecosystem values because probability of willingness to participate decreases by 0.14 to 0.38 from those who consider ecosystem services as important to those who consider it to be unimportant, with reference to those who consider ecosystem services to be very important. These results are worth nothing because forestland owners in South Carolina who enjoy forest ecosystem services other than timber can be the best to contact to participate in carbon markets. Also, in the restricted model, the marginal effect of the gender variable shows that probability of willingness to accept is higher by 0.12 , given that a forestland owner is a male compared with a female. Similar studies find that more male forestland owners are willing to participate in carbon markets than females (Miller et al. 2012; Dickinson 


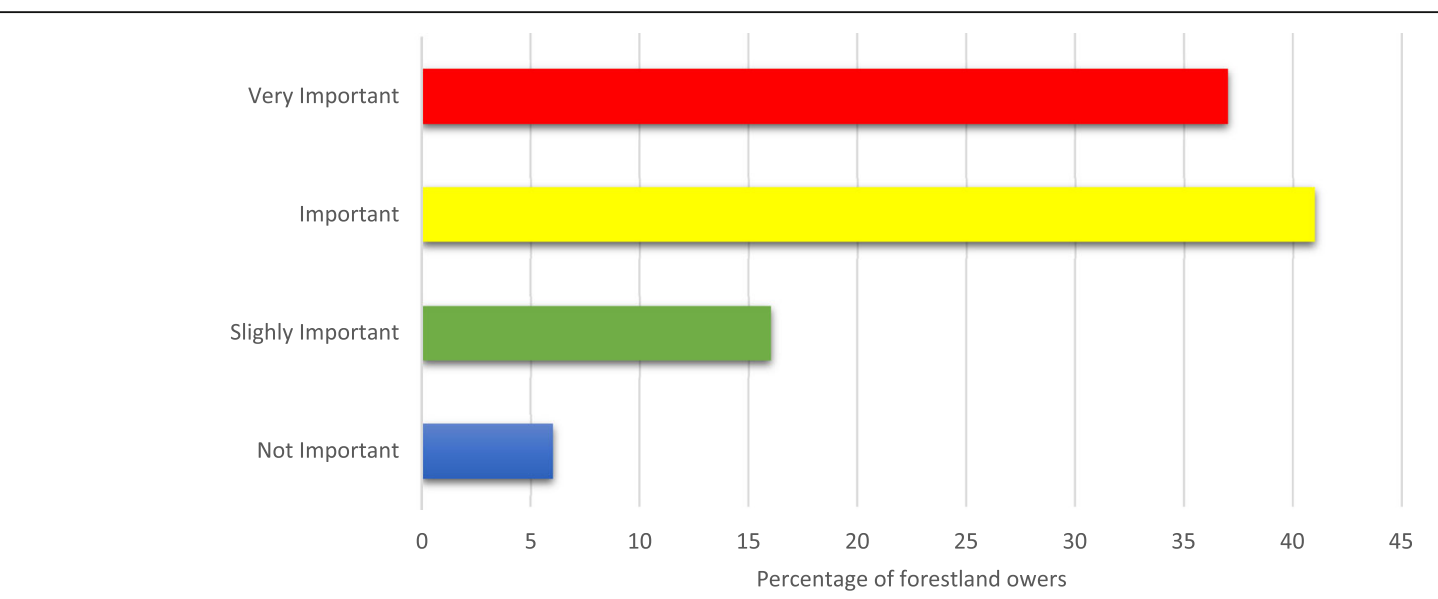

Fig. 2 Forestland owners' responses to importance of ecosystem services

et al. 2012). This could be an indication of gender differences in risk aversion with females not willing to take risk placing their forestlands under 100 years of easements, as stipulated in the forest offset protocol of the CA-CTP. The mean WTA from the restricted model is $\$ 68.50$ and the median is $\$ 70.51$.

In the unrestricted model shown in the last two columns in Table 3, the same variables as in the restricted model are significant in addition to scientist 4 and government4 variables. From the marginal effects of the variables representing importance of ecosystem services as one of the reasons for owning a forestland, the probability of willingness to participate decreases by 0.16 to 0.34 from those who consider ecosystem services to be important to those who consider it to be unimportant. The marginal effect of the science4 variable show that probability of willingness to participate goes down by 0.34 , given that a forestland owner does not trust information about climate change from a scientist compared with when the trust is high. Similarly, as shown by the marginal effect of government4, probability of willingness to participate decreases by 0.23 for forestland owners who do not trust climate change information from government compared with those with high trust. The marginal effect of the gender variable shows that probability of willingness to accept is higher by 0.13 for males than for female forestland owners. We investigated the gender variable in detail by interacting it with some of the important variables including bid, forestland acres, education, and income but did not find any significant pattern in the results. Our statistical test of how information about the U.S. withdrawal from the Paris agreement

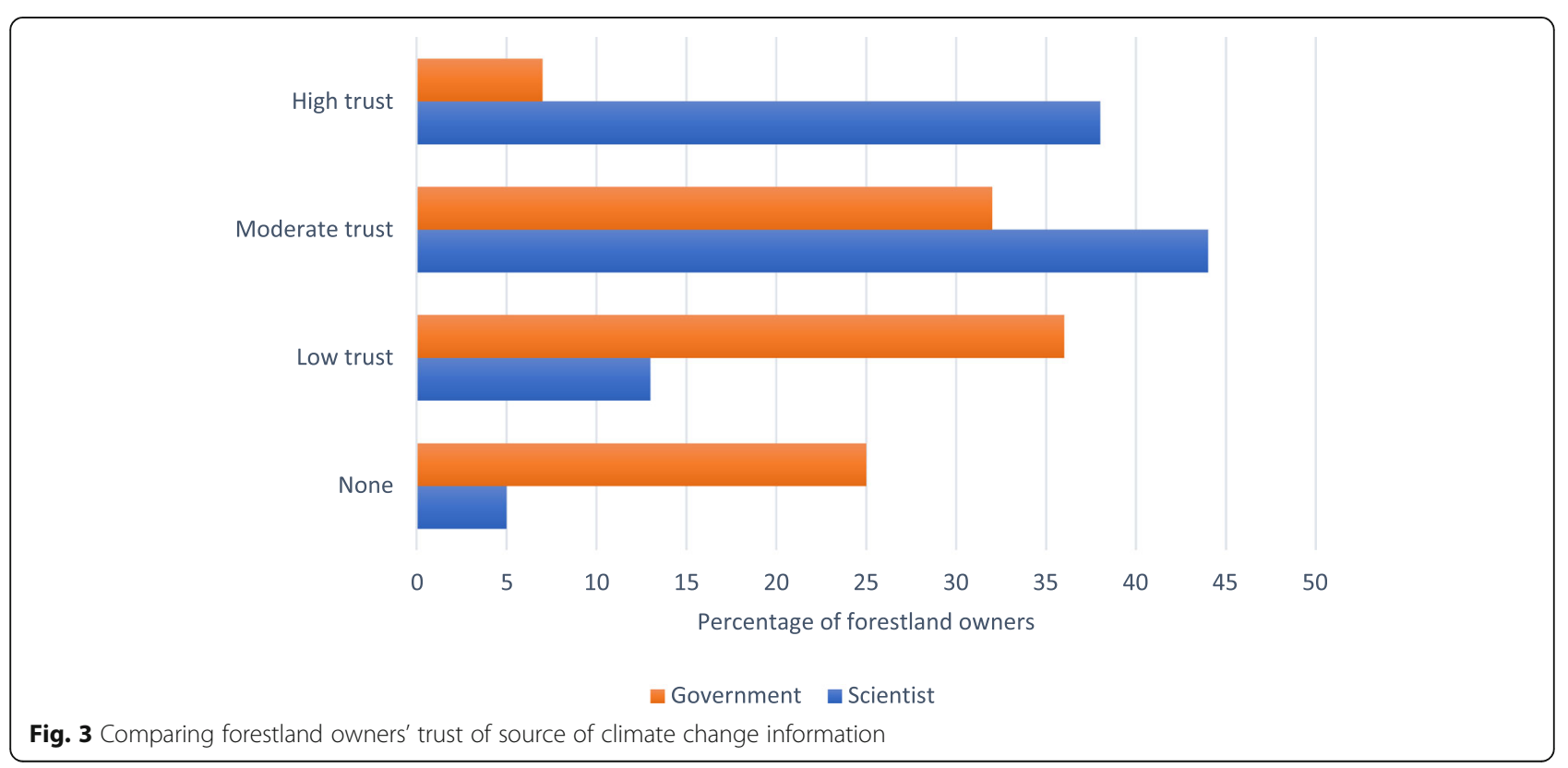




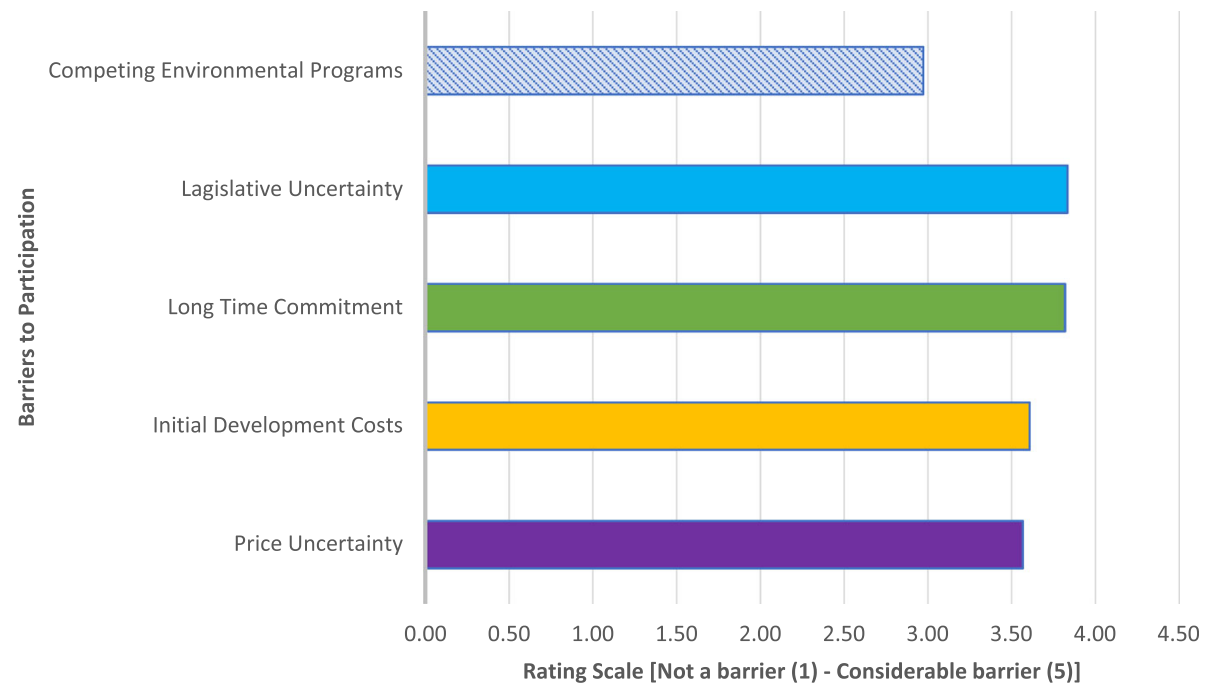

Fig. 4 Forestland owners perceived barriers to participation in carbon market

impact private forestland owners' decisions to participate in carbon market was not significant. We explored the Paris agreement variable further through interactions with other variables, similar to the treatment of the gender variable, but none was significant. The estimated mean WTA from the unrestricted model is $\$ 66.94$ and the median is $\$ 63.68$.

In choosing between the two models, we consider the unrestricted model to be our best model, given that its loglikelihood and McFadden's pseudo R-squared values, which are the only criteria available to us are higher than those of the restricted model. So, our conclusion is based on the unrestricted model.

\section{Conclusions}

To achieve low carbon economy, the Global Solutions Act of 2006 was passed in California to reduce greenhouse gas emissions. CARB implemented the cap-and-trade program in the state to achieve the environmental objective of reduced emissions at lowest cost. CARB allows carbon trading, up to $8 \%$ of an entity's limit, between compliance entities in California and offset projects including forest offset projects in other states within the contiguous United States.

This study investigated South Carolina forestland owners' willingness to generate and sell carbon credits to California's cap-and-trade program. We used a sample

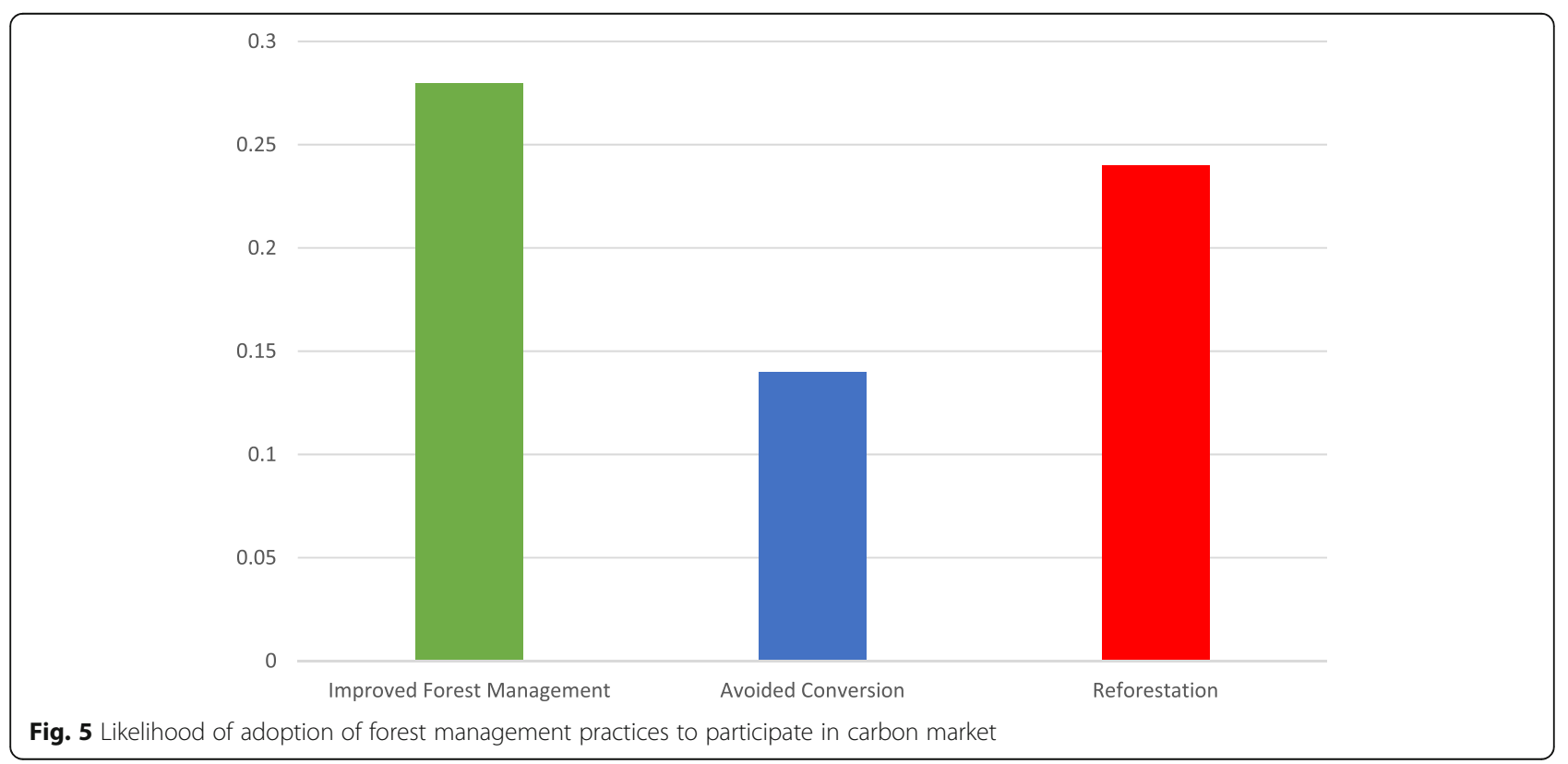


Table 3 Probit estimates and marginal effects of willingness to participate in carbon market

\begin{tabular}{|c|c|c|c|c|}
\hline \multirow[t]{2}{*}{ Variable } & \multicolumn{2}{|l|}{ Restricted Model } & \multicolumn{2}{|l|}{ Unrestricted Model } \\
\hline & Coeff. (Std. Err.) & Marg. Eff. (Std. Err.) & Coeff. (Std. Err.) & Marg. Eff. (Std. Err.) \\
\hline Bid & $0.007(0.003)^{b}$ & $0.003(0.001)^{b}$ & $0.008(0.003)^{b}$ & $0.003(0.001)^{b}$ \\
\hline Paris & $-0.03(0.13)$ & $-0.01(0.05)$ & $0.01(0.14)$ & $0.004(0.05)$ \\
\hline Forestland & $0.000004(0.00001)$ & $0.000002(0.000005)$ & $0.0000003(0.00001)$ & $0.0000001(0.000005)$ \\
\hline Easement & $0.001(0.15)$ & $0.0005(0.06)$ & $-0.009(0.16)$ & $-0.003(0.06)$ \\
\hline Ecosystems2 & $-0.37(0.15)^{b}$ & $-0.14(0.06)^{b}$ & $-0.41(0.15)^{\mathrm{a}}$ & $-0.16(0.06)^{\mathrm{a}}$ \\
\hline Ecosystems3 & $-0.57(0.19)^{a}$ & $-0.22(0.07)^{a}$ & $-0.55(0.20)^{\mathrm{a}}$ & $-0.21(0.08)^{a}$ \\
\hline Ecosystems4 & $-0.98(0.33)^{a}$ & $-0.38(0.13)^{a}$ & $-0.87(0.38)^{b}$ & $-0.34(0.14)^{b}$ \\
\hline Scientist2 & & & $-0.11(0.16)$ & $-0.04(0.06)$ \\
\hline Scientist3 & & & $-0.06(0.24)$ & $-0.02(0.09)$ \\
\hline Scientist4 & & & $-0.88(0.46)^{c}$ & $-0.34(0.18)^{c}$ \\
\hline Government2 & & & $-0.30(0.27)$ & $-0.12(0.10)$ \\
\hline Government3 & & & $-0.42(0.28)$ & $-0.16(0.11)$ \\
\hline Government4 & & & $-0.60(0.31)^{c}$ & $-0.23(0.12)^{c}$ \\
\hline Gender & $0.32(0.18)^{c}$ & $0.12(0.07)^{c}$ & $0.33(0.19)^{c}$ & $0.13(0.07)^{c}$ \\
\hline Education & $-0.007(0.03)$ & $-0.003(0.01)$ & $-0.02(0.04)$ & $-0.008(0.01)$ \\
\hline Income & $0.000001(0.000001)$ & $0.0000005(0.0000004)$ & $0.000002(0.000001)$ & $0.0000006(0.0000004)$ \\
\hline Constant & $-0.50(0.61)$ & & $0.12(0.68)$ & \\
\hline Log likelihood & -257.51 & & -241.13 & \\
\hline Chi2 & $26.77^{a}$ & & $41.13^{\mathrm{a}}$ & \\
\hline Mean WTA (\$) & 68.80 & & 66.94 & \\
\hline Median WTA (\$) & 70.51 & & 63.68 & \\
\hline Obs. & 401 & & 387 & \\
\hline
\end{tabular}

Note: ${ }^{a}$ is significance at the $1 \%$ level, ${ }^{b}$ is significance at the $5 \%$ level, ${ }^{c}$ is significance at the $10 \%$ level. The omitted variable categories are: Ecosystems 1 , Scientist 1 , and Government1

of 784 private forestland owners' responses to a contingent valuation survey in SC. As part of the main objectives of this study, our estimated average willingness to accept (WTA) in order to supply carbon credits to California's carbon market was $\$ 67$ per acre per year. Birdsey (1992) estimate average carbon storage of forestland in SC to be in the range of 110,000 to 140,000 pounds per acre. Given $\$ 11$ per ton of carbon dioxide $\left(\mathrm{CO}_{2}\right)$ as the lowest price of carbon credit at the time this survey was conducted, and a worst-case scenario of 55 ton per acre $(110,000$ pounds/acre) of minimum carbon storage of forestland in South Carolina, forestland owners can earn a minimum of $\$ 605$ per acre in revenue to participate in California's carbon market. The average WTA is the minimum compensation per acre the landowners are willing to accept, even though potential revenue of $\$ 605$ per acre is likely given carbon sequestration potential of the State's forestlands. The State's forestland owners' knowledge in carbon sequestration is limited and some of them even indicated that they needed more information about California's carbon market to help them with their decisions to participate.
Our results show that factors such as gender of forestland owners, importance of ecosystem services provided by forest ecosystems, trusts in climate change information from scientist or government, and the dollar value a forestland owner is offered to participate in the carbon market impact forestland owners' willingness to participate in the program. The probability of forestland owners' willingness to participate in the California cap-and-trade program increases with the dollar values offered to them. Male forestland owners have a higher likelihood of participation than female forestland owners. Forestland owners who consider forest ecosystem services other than timber to be important to them have a higher probability of participating in the carbon market than those who do not consider it to be important. Another important finding is that forestland owners who trust in information about climate change from scientists or the government have a higher probability of willingness to participate in carbon markets than those who do not. We did not find any impact of the United States withdrawal from the Paris Agreement on forestland owners' willingness to participate in California's carbon market. 
Various factors hinder landowners' ability to participate in carbon markets. Forestland owners in SC consider legislative uncertainty and long-time commitment in California's carbon market as the main barriers to participation. Our data also show that about $28 \%, 24 \%$, and $14 \%$ of forestland owners are likely to adopt improved forest management, reforestation, and avoided conversion forest management practices, respectively, to participate in California's cap-and-trade program. About $79 \%$ of forestland owners agreed to aggregate their forestlands with others to participate in the carbon market. Another important information from our study is average number of years a forestland is owned in the State. This number of years turns out to be about 27 , which is far below 100 years as the time commitment for participation in the California's carbon market.

This study is subject to some limitations. Participation in a carbon market by SC forestland owners will depend on forestland availability in the state, and not only the amount they are willing to accept. This research is unable to determine how much forestland is available in the State to be used in a carbon market. Risk preferences of forestland owners, which our research also fails to elicit can also impact willingness to participate in a carbon market. Therefore, we suggest future research on carbon market in the state should consider evaluating forestland availability and risk preferences of forestland owners.

\section{Endnotes}

${ }^{1}$ Alabama, Arkansas, East Oklahoma, East Texas, Georgia, Florida, Louisiana, Mississippi, North Carolina, South Carolina, Virginia.

\section{Abbreviations}

AB 32: Assembly Bill 32; AC: Avoided conversion; APD: Authorized Project Designee; BMPs: Best Management Practices; CA-CTP: California's Cap-andTrade Program; CARB: California Air Resources Board; CDF: Cumulative distribution function; $\mathrm{CO}_{2}$ : Carbon dioxide; $\mathrm{GHG}$ : Greenhouse gas; IFM: Improved forest management; NOAA: National Oceanic and Atmospheric Administration; SC: South Carolina; WTA: Willingness to accept

\section{Acknowledgements}

We thank the South Carolina Natural Resources Conservation Service for funding this research. We also thank many individuals including Dr. William Connor and Dr. Tom O'Halloran at Clemson University's Baruch Institute for their useful comments in the development of our survey questionnaires, and Mr. Guy Sabin at SC Forestry Commission for helping us with contact information of forestland owners. Most especially, we thank participants of the 2018 "A Community on Ecosystem Services (ACES)" conference and the two anonymous reviewers for their insightful comments.

\section{Funding}

The research was funded by the South Carolina Natural Resources Conservation Service (SC NRCS) with grant number 2021917.

\section{Availability of data and materials}

The survey data used for this study are available from the corresponding author on reasonable request.

\section{Authors' contributions}

MA wrote the survey questionnaire, analyzed and interpreted the survey data on the willingness to participate and prepared the manuscript. MM was a major contributor in writing the manuscript and also verified the methods used were correct to achieve the main goals of the research. BS reviewed the manuscript and provided insights into forest management practices to include in the manuscript preparation. All authors read and approved the final manuscript.

Ethics approval and consent to participate

Our questionnaire was approved by Clemson University Institutional Review Board with approval number IRB2017-137.

Consent for publication

Not applicable.

\section{Competing interests}

The authors declare that they have no competing interests.

Received: 16 August 2018 Accepted: 1 March 2019

Published online: 25 March 2019

\section{References}

Arrow K, Solow R, Portney PR, Leamer EE, Radner R, Schuman H (1993) Report of the NOAA panel on contingent valuation. Fed Regist 58(10):4601-4614

Birdsey RA (1992) Carbon storage and accumulation in United States forest ecosystems. In: Gen. Tech. Rep. WO-59. US Department of Agriculture, Forest Service, Washington Office, Washington DC, p 51

Bonan GB (2008) Forests and climate change: forcings, feedbacks, and the climate benefits of forests. Science 320(5882):1444-1449

Brandeis TJ, Hartwell A, Brandeis A, Randolph K, Oswalt S (2016) Forests of South Carolina, 2015 (resource update FS-102). USDA Forest Service, Southern Research Station, Asheville

Butler, B., Hewes, J.H., Dickinson, B.J., Andrejczyk, K., Butler, S.M. and MarkowskiLindsay, M., 2016. USDA forest service national woodland owner survey: national, regional, and state statistics for family forest and woodland ownerships with 10+ acres, 2011-2013. Res. Bull. NRS-99. Newtown Square: US Department of Agriculture, Forest Service, Northern Research Station. 39, 99, 1-39

Buys L, Aird R, van Megen K, Miller E, Sommerfeld J (2014) Perceptions of climate change and trust in information providers in rural Australia. Public Underst Sci 23(2):170-188

CARB (2015a) Cap-and-trade program. https://www.arb.ca.gov/cc/capandtrade/ capandtrade.htm. Accessed: 31 Oct 2017

CARB (2015b). California Air Resources Board. Compliance Offset Protocol U.S. Forest Projects. June 2015. https://www.arb.ca.gov/cc/capandtrade/protocols/ usforest/usforestprojects_2015.htm. Accessed 31 Oct 2017

Charnley S, Diaz D, Gosnell H (2010) Mitigating climate change through small-scale forestry in the USA: opportunities and challenges. Small Scale For 9(4):445-462

Cook SL, Ma Z (2014) The interconnectedness between landowner knowledge, value, belief, attitude, and willingness to act: policy implications for carbon sequestration on private rangelands. J Environ Manag 134:90-99

Dickinson BJ, Stevens TH, Lindsay MM, Kittredge DB (2012) Estimated participation in US carbon sequestration programs: a study of NIPF landowners in Massachusetts. J For Econ 18(1):36-46

Flint L, Flint A, Stern M, Mayer A., Vergara S, Silver W, Casey F, Franco F, Byrd K, Sleeter B, Alvarez P, Creque J, Estrada T, Cameron D (U.S. Geological Survey) (2018) Increasing soil organic carbon to mitigate Greenhouse gases and increase climate resiliency for California. California's fourth climate change assessment, California natural resources agency. Publication number: CCCA4CNRA-2018-006. http://www.climateassessment.ca.gov/techreports/ agriculture.html. Accessed: 14 Jan 2018

Green Assets (2017) What is a carbon credit? http://www.green-assets.com/. Accessed: 2 Aug 2017

Haab TC, McConnell KE (2003) Valuing environmental and natural resources: the econometrics of non-market valuation. Edward Elgar, Northampton

Hamrick K, Galant M (2017) Unlocking potential: state of the voluntary carbon markets 2017. Ecosystems marketplace, a forest trend initiative, Washington D.C. https:/ www.forest-trends.org/publications/unlocking-potential/. Accessed 31 Oct 2017.

Hanemann WM (1984) Welfare evaluations in contingent valuation experiments with discrete responses. Am J Agric Econ 66(3):332-341 
Hein $L$ (2017) Using forest carbon credits to offset emissions in the downstream business. CONCAWE Rev 26(1):4-5

Hsia-Kiung K, Reyna E, O'Connor T (2014) Carbon market California: a comprehensive analysis of the golden state's cap-and-trade program (year one: 2012-2013). Environmental Defense Fund. https:/www.edf.org/sites/ default/files/ca-cap-and-trade_1yr_22_web.pdf. Accessed 31 Oct 2017

Jackson RB, Randerson JT, Canadell JG, Anderson RG, Avissar R, Baldocchi DD, Bonan GB, Caldeira K, Diffenbaugh NS, Field CB, Hungate BA (2008) Protecting climate with forests. Environ Res Lett 3(4):044006

Kelly EC, Gold GJ, Di Tommaso J (2017) The willingness of non-industrial private forest owners to enter California's carbon offset market. Environ Manage 60(5):882-895

Khanal PN, Grebner DL, Munn IA, Grado SC, Grala RK, Henderson JE (2017) Evaluating non-industrial private forest landowner willingness to manage for forest carbon sequestration in the southern United States. Forest Policy Econ 75:112-119

Loomis J (2014) 2013 WAEA Keynote Address: Strategies for Overcoming Hypothetical Bias in Stated Preference Surveys. J Agric Resour 39(1):34-46. Retrieved from http://www.jstor.org/stable/44131313

Markowski-Lindsay M, Stevens T, Kittredge DB, Butler BJ, Catanzaro P, Dickinson BJ (2011) Barriers to Massachusetts forest landowner participation in carbon markets. Ecol Econ 71:180-190

Miller KA, Snyder SA, Kilgore MA (2012) An assessment of forest landowner interest in selling forest carbon credits in the Lake states, USA. Forest Policy Econ 25:113-122

Mitchell RC, Carson RT (2013) Using surveys to value public goods: the contingent valuation method. Rff Press. New York. https://doi.org/10.4324/ 9781315060569

Poudyal NC, Siry JP, Bowker JM (2010) Urban forests' potential to supply marketable carbon emission offsets: a survey of municipal governments in the United States. Forest Policy Econ 12(6):432-438

Silver WL, Vergara SE, Mayer A (2018) Carbon sequestration and greenhouse gas mitigation potential of composting and soil amendments on California's rangelands

South Carolina Forestry Commission (2010) South Carolina's statewide forest resource assessment and strategy. Conditions, trends, threats, benefits, and issues

South Carolina Forestry Commission (2018) South Carolina's best management practices for forestry. Accessed 30 Dec 2018 at https://www.state.sc.us/forest/ bmpmanual.pdf

Villa JA, Bernal B (2018) Carbon sequestration in wetlands, from science to practice: an overview of the biogeochemical process, measurement methods, and policy framework. Ecol Eng 114:115-128

Watson JE, Evans T, Venter O, Williams B, Tulloch A, Stewart C, Thompson I, Ray JC, Murray K, Salazar A, McAlpine C (2018) The exceptional value of intact forest ecosystems. Nat Ecol Evol 2:599-610

\section{Submit your manuscript to a SpringerOpen ${ }^{\circ}$ journal and benefit from:}

- Convenient online submission

- Rigorous peer review

- Open access: articles freely available online

- High visibility within the field

- Retaining the copyright to your article

Submit your next manuscript at $\boldsymbol{\nabla}$ springeropen.com 